\title{
SENTRA KeRAJINAN KULIT \\ SEBAGAI KaWASAN WiSATA INDUSTRI Di KABUPATEN MAGETAN
}

\author{
Zarra Primita Aryana, Sumaryoto, Leny Pramesti \\ Program Studi Arsitektur \\ Fakultas Teknik \\ Universitas Sebelas Maret Surakarta \\ Email : zarraprimary@gmail.com
}

\begin{abstract}
The development of Leather Crafting Center "Sawo Street" in Magetan Regency is supported by the increasing numbers of tourists who visit the place, the increasing numbers of leather craft showrooms, the availability of development area, great amount of raw materials, and the local crafters as the embryo of this industrial tourism. Therefore, the objective of this design is about achieving an area design which provides the facilities for shopping tourism activities, especially for leather crafting products, facilitate industrial tourism activities and training activities for the crafters into the building design that expresses local area architecture as the land mark of Magetan Regency. The problem of the design is about how the finishing of mass system of the buildings in the area and the expression of buildings with local architecture can be interpreted into the area design of Leather Crafting Center "Sawo Street" in Magetan Regency. The method used in this study is architecture design method. The achieved result is the design of leather crafting shopping center, industrial tourism, and training center area in the form of supporting building facilities in a tourism area in order to optimize the function of Leather Crafting Center "Sawo Street" in Magetan Regency as industrial tourism area.
\end{abstract}

Key words: Architecture, Leather Crafting Center, Sawo Street, Tourism Area.

\section{PENDAHULUAN}

Kulit dan produk kulit merupakan salah satu komoditi ekspor Indonesia yang kompetitif di pasar global (http://formatnews.com/komoditi-eksporindonesia/). Pusat industri penyamakan kulit dan sentra kerajinan kulit di Indonesia terletak di Pulau Jawa. Jawa Timur merupakan propinsi dengan jumlah perusahaan penyamakan kulit terbanyak di Indonesia (Profil Spesifikasi Kulit Tersamak Indonesia, 2007), hal ini berdampak pada perkembangan jumlah sentra kerajinan kulit yang salah satunya di Kabupaten Magetan.

Terdapat 136 unit usaha kerajianan kulit tersebar di beberapa kecamatan di Kabupaten Magetan (Permenperind_No.130_2011), yang mampu menyerap ratusan tenaga kerja. Dengan nilai investasi lebih dari Rp $10 \mathrm{M}$ industri kerajinan kulit mampu memberikan nilai produksi lebih dari Rp $55 \mathrm{M}$, data diambil dari www.magetankab.go.id. Pengembangan industri kulit oleh Pemerintah dilakukan dengan membentuk pusat atau Sentra
Kerajianan Kulit di Jalan Sawo, Kelurahan Selosari, Kecamatan Magetan.

Sentra Kerajinan Kulit Jalan Sawo Kabupaten Magetan ini merupakan kawasan yang potensial untuk dikembangkan karena mempunyai potensi lokasi strategis, produk berkuaitas, serta bahan baku yang melimpah. Berkembangnya Jalan Sawo menjadi icon wisata kerajinan kulit Kota Magetan belum diimbangi dengan penataan kawasan yang baik sehingga mengakibatkan permasalahan yaitu kendaraan yang terhambat oleh pejalan kaki, ruang parkir yang tidak memadai, perkembangan keahlian pengrajin yang lamban, dan belum tersedianya fasilitas bagi wisatawan.

Perlu pengembangan serta penataan kembali kawasan Sentra Industri Kulit di Jalan Sawo tersebut untuk mengatasi permasalahanpermasalahan yang ada berupa: redesain showroom kerajinan kulit, penambahan fasilitas balai pelatihan untuk pengrajin, penataan pedestrian dan penambahan fasilitas penunjang kawasan wisata. 


\section{METODE}

Dalam tugas akhir dengan judul Sentra Kerajinan Kulit Jalan Sawo di Kabupaten Magetan sebagai Kawasan Wisata Industri ini, metode perancangan yang dikembangkan adalah bagaimana merancang kawasan Jalan Sawo menjadi sebuah kawasan wisata industri, melalui:

A. Pengembangan Kawasan

Pengembangan kawasan Sentra

Kerajinan Kulit Jalan Sawo didasarkan pada fungsi utama kawasan, yaitu:

1. Fasilitas Penunjang Pemukiman

Merupakan wadah untuk kegiatan bersama penduduk lokal yang membutuhkan tempat lebih privat.

2. Balai Pelatihan

Merupakan wadah untuk kegiatan pelatihan para pengrajin.

3. Jalur Pedestrian

Merupakan wadah untuk kegiatan wisata belanja kerajinan kulit.

4. Taman Parkir

Merupakan wadah untuk kegiatan parkir pengunjung kawasan wisata, sebagai solusi pengembalian fungsi utama Jalan Sawo.

5. Kantor Pengelola

Merupakan wadah untuk kegiatan pengawasan dan pengelolaan kawasan wisata.

6. Fasilitas Penunjang Kawasan Wisata Industri

Merupakan wadah untuk kegiatan penunjang sebagai kawasan wisata.

B. Redesain Kawasan

Redesain dilakukan pada showroomshowroom kerajinan kulit di koridor Jalan Sawo. Redesain showroom disesuaikan dengan luas bangunan dan dikelompokkan ke dalam tipe berdasarkan fungsi yang ada, berupa:

1. Tipe A

Fungsi bangunan sebagai showroom dan tempat tinggal.

2. Tipe B

Fungsi bangunan sebagai showroom dan tempat produksi.

3. Tipe $\mathrm{C}$

Fungsi bangunan sebagai showroom tunggal.

\section{ANALISIS}

A. Analisis Peruangan

Berdasarkan pelaku dan pola kegiatannya maka ruang-ruang yang dibutuhkan dalam pengembangan kawasan Sentra Industri Kerajinan Kulit Jalan Sawo Kabupaten Magetan adalah sebagai berikut:

Tabel 1. Kebutuhan Ruang

\begin{tabular}{|c|c|c|}
\hline $\begin{array}{l}\text { Kelompok } \\
\text { Ruang }\end{array}$ & Kegiatan & $\begin{array}{l}\text { Kebutuhan } \\
\text { Ruang }\end{array}$ \\
\hline \multirow{9}{*}{$\begin{array}{l}\text { Balai } \\
\text { Pelatihan }\end{array}$} & $\begin{array}{l}\text { Memarkir } \\
\text { kendaraan }\end{array}$ & $\begin{array}{l}\text { Tempat parkir } \\
\text { pengrajin }\end{array}$ \\
\hline & Mengganti pakaian & $\begin{array}{l}\text { Ruang ganti \& } \\
\text { loker }\end{array}$ \\
\hline & $\begin{array}{l}\text { Produksi kerajinan } \\
\text { kulit }\end{array}$ & $\begin{array}{l}\text { Ruang } \\
\text { produksi }\end{array}$ \\
\hline & $\begin{array}{l}\text { Pemeriksaan } \\
\text { kualitas produk }\end{array}$ & $\begin{array}{l}\text { Ruang } \\
\text { pengendali } \\
\text { mutu }\end{array}$ \\
\hline & $\begin{array}{l}\text { Memamerkan } \\
\text { produk }\end{array}$ & $\begin{array}{l}\text { Ruang pamer } \\
(\text { show-room })\end{array}$ \\
\hline & $\begin{array}{l}\text { Pelatihan pengrajin } \\
\& \text { ibu rumah tangga }\end{array}$ & $\begin{array}{l}\text { Ruang } \\
\text { seminar }\end{array}$ \\
\hline & Beristirahat & $\begin{array}{l}\text { Ruang makan } \\
\& \text { istirahat }\end{array}$ \\
\hline & Beribadah & Musholla \\
\hline & Metabolisme & Toilet \\
\hline \multirow{9}{*}{$\begin{array}{l}\text { Fasilitas } \\
\text { Penunjang } \\
\text { Kawasan } \\
\text { Wisata }\end{array}$} & $\begin{array}{l}\text { Menampilkan } \\
\text { sejarah dan seluk } \\
\text { beluk kawasan }\end{array}$ & Mini galeri \\
\hline & Promosi wisata & Spot-rest \\
\hline & $\begin{array}{l}\text { Memberikan } \\
\text { informasi }\end{array}$ & $\begin{array}{l}\text { Ruang } \\
\text { informasi }\end{array}$ \\
\hline & Menjaga keamanan & Pos jaga \\
\hline & $\begin{array}{l}\text { Belanja kue } \\
\text { tradisional }\end{array}$ & $\begin{array}{l}\text { Gerobak kaki } \\
\text { lima }\end{array}$ \\
\hline & Istirahat \& makan & Tempat makan \\
\hline & $\begin{array}{l}\text { Memarkir } \\
\text { kendaraan }\end{array}$ & Tempat parkir \\
\hline & Beribadah & Masjid \\
\hline & Metabolisme & Unit toilet \\
\hline
\end{tabular}

Pada Tabel 1. terlihat kebutuhan peruangan yang dibutuhkan dalam pemenuhan kawasan wisata industri.

B. Analisis Redesain Showroom

Redesain showroom ditentukan berdasarkan fungsi dan luas bangunan yang disesuikan dengan masingmasing luasan tipe bangunan. yaitu : 
Tipe A (bangunan sebagai showroom dan tempat tinggal)

Ruang yang direncanakan berupa showroom, ruang tidur, ruang tamu, ruang keluarga, dapur, tempat ibadah, $\mathrm{km} / \mathrm{wc}$ dan carport.

Tipe B (bangunan sebagai showroom dan tempat produksi)

Ruang yang direncanakan berupa showroom, ruang stok barang, ruang bahan, tempat produksi, ruang tamu, tempat ibadah, $\mathrm{km} / \mathrm{wc}$ dan parkir.

$>$ Tipe $\mathrm{C}$ (bangunan sebagai showroom tunggal)

Ruang yang direncanakan berupa showroom, ruang stok barang, ruang tamu, ruang kerja, tempat ibadah dan km/wc.

\section{Analisis Pencapaian}

a. Tujuan

Menentukan main entrance dan side entrance pada tapak.

b. Dasar pertimbangan:

- Sirkulasi lalu lintas makro di sekitar tapak, disesuaikan dengan eksisting sehingga tidak menimbulkan masalah lalu lintas / kemacetan terhadap jalan utama di sekitar kawasan.

- Kemudahan pencapaian dari jalan utama.

- Jalur pedestrian dalam kawasan.

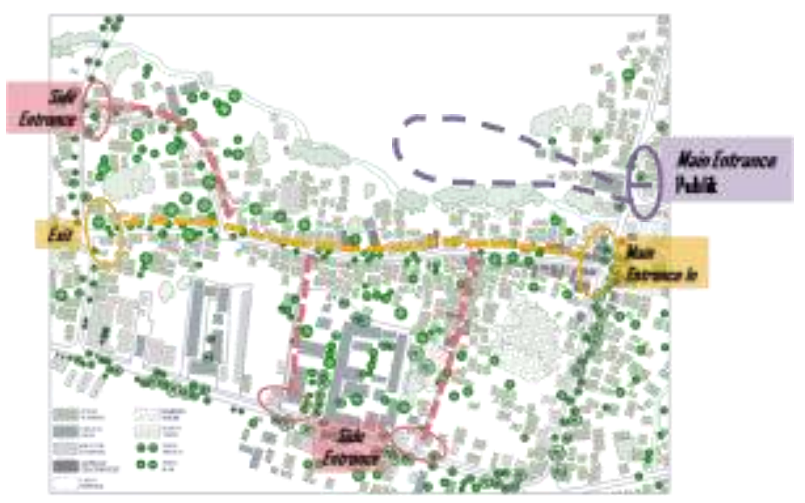

Gambar 1. Analisa Pencapaian Kawasan

Pada Gambar 1. ditunjukkan hasil analisa pencapaian berupa letak main entrance, side entrance, dan pola sirkulasi dalam kawasan.
D. Analisis Penataan Kawasan

1. Tujuan: menentukan letak bangunan fasilitas penunjang wisata pada area pengembangan

2. Dasar Pertimbangan:

- Penataan kawasan memanfaatkan lahan potensial, baik yang terdapat dalam kawasan maupun di sekitar kawasan.

- Fasilitas penunjang pemukiman bersifat privat bagi penduduk lokal kawasan.

- Fasilitas penunjang kawasan wisata mudah ditemui oleh wisatawan.

- Balai pelatihan merupakan bagian dari kawasan wisata yang dapat menjadi kesatuan wadah tersendiri.

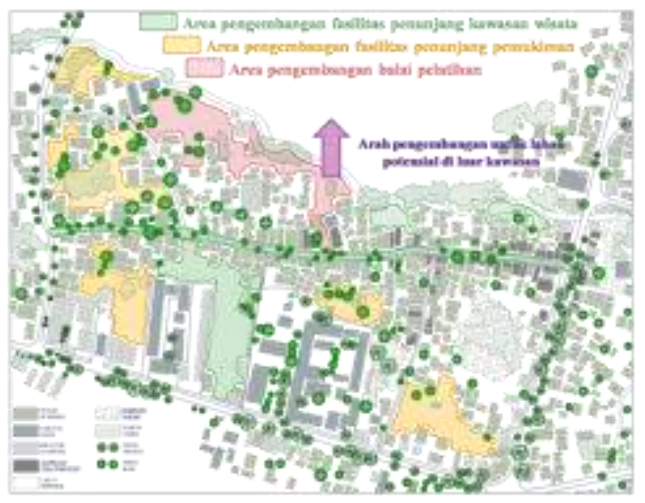

Gambar 2. Analisa Penataan Kawasan

Pada Gambar 2. ditunjukkan letak lahan potensial sebagai area pengembangan kawasan wisata industri.

E. Analisis Kontur

1. Tujuan: menunjukkan garis kontur yang terdapat dalam kawasan serta menentukan penyelesaian desain

2. Dasar pertimbangan:

- Garis kontur diambil berdasarkan perbedaan ketinggian lahan pada kawasan yang dibatasi dengan talut dan prigi batu.

- Garis kontur pada lahan potensial dipertahankan untuk menjaga keaslian kawasan. 
- Untuk menahan tanah dari bahaya longsor, maka daerah di sekitar perbedaan kontur tersebut ditanami pepohonan. Sedangkan untuk menahan beban bangunan yang terletak berdekatan dengan garis kontur, maka digunakan talut.

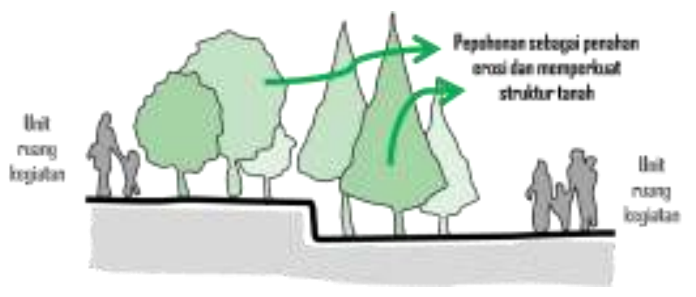

Gambar 3. Potongan Kontur I

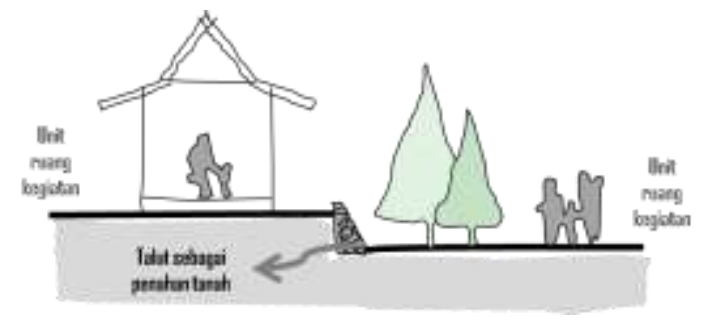

Gambar 4. Potongan Kontur II

Pada Gambar 3. dan Gambar 4. ditunjukkan penyelesaian disain pada garis kontur yang ada dalam kawasan.

F. Analisis Matahari

1. Tujuan: menentukan respon terhadap paparan sinar matahari.

2. Dasar Pertimbangan:

- Pengaruh sinar matahari pagi (sebelum pukul 09.00) : sinarnya tidak menyengat dan baik untuk kesehatan sehingga perlu dioptimalkan pemakaiannya.

- Pengaruh sinar matahari siang : arah datang sinar tepat dari atas, terasa panas dan menyengat juga menyilaukan sehingga perlu dieliminasi.

- Pengaruh sinar matahari sore (setelah pukul 15.00) : sinarnya menyilaukan dan tidak baik untuk kesehatan.

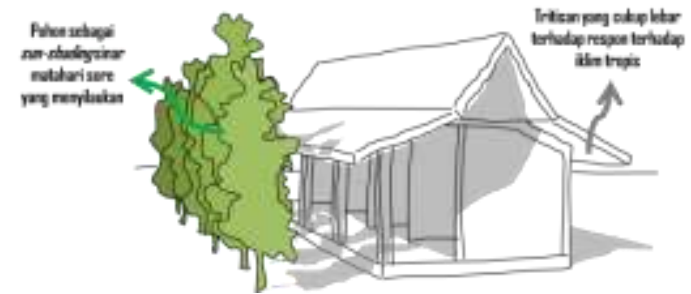

Gambar 5. Sketsa Barier Pohon dan Tritisan

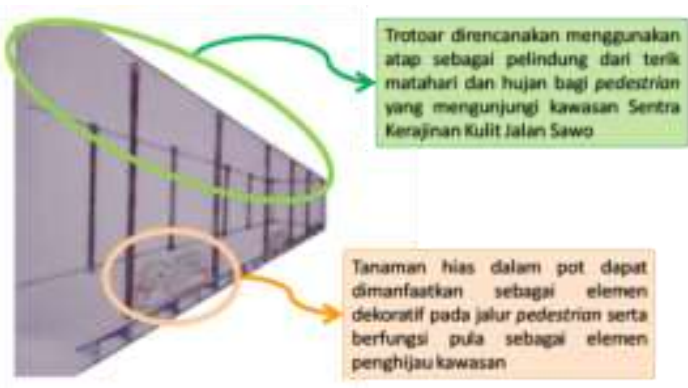

Gambar 6. Sketsa Jalur Pedestrian

Pada Gambar 5. dan Gambar 6. ditunjukkan penyelesaian disain bangunan sebagai respon paparan sinar matahari.

F. Analisa Angin

1. Tujuan: menentukan arah dan bukaan pada bangunan untuk memaksimalkan potensi angin dalam kawasan.

2. Dasar pertimbangan: Bangunan yang mengisi sebagian besar kawasan tidak menghalangi pergerakan angin karena ketinggian bangunan rata-rata hanya 1-2 lantai. Pada pemukiman dan pada keseluruhan kawasan Sentra Industri Kerajinan Kulit Jalan Sawo Kabupaten Magetan, angin yang berhembus kencang adalah angin dari arah Barat Daya dan Utara kawasan karena masih berupa lahan persawahan.

3. Hasil analisa berupa pemanfaatan angin potensial dalam kawasan melalui letak bukaan yang sesuai dan penerapan sirkulasi silang.

G. Analisis View

1. Tujuan: menentukan point of view masa bangunan serta menentukan area point of view menuju kawasan. 
2. Dasar pertimbangan: Analisa view dilakukan untuk mengoptimalkan view yang positif. View yang akan dianalisa adalah view dari tapak dan view menuju tapak. Analisa view dari tapak bertujuan untuk menentukan point of view pada bangunan dalam kawasan. Analisa view menuju tapak bertujuan untuk menentukan view positif dari luar kawasan sehingga bangunan pada view tersebut dapat lebih ditonjolkan.

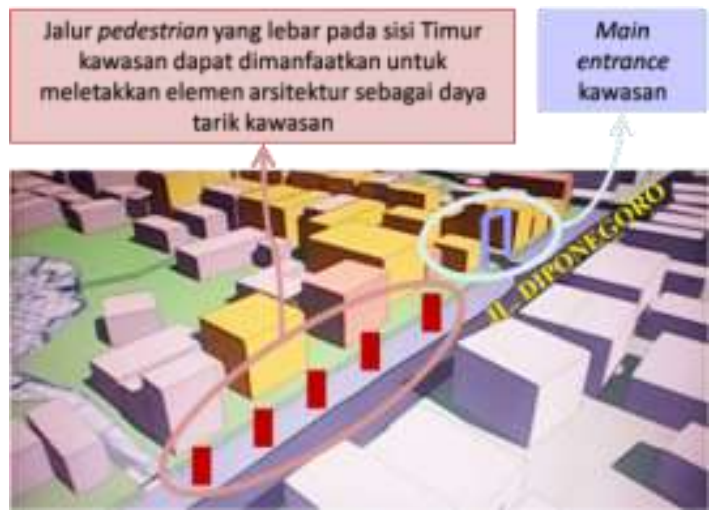

Gambar 7. View Elemen Arsitektural

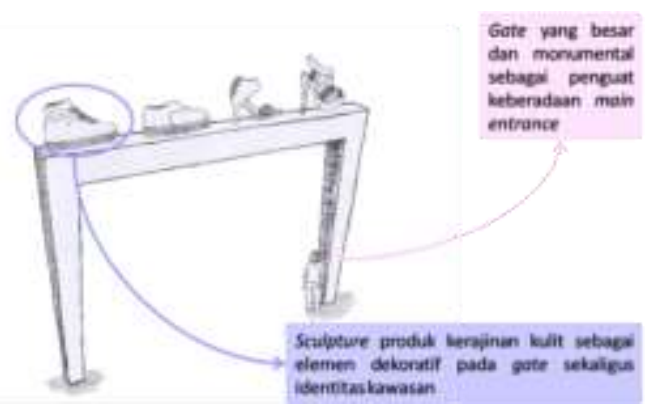

Gambar 8. Sketsa Gate pada Main Entrace

Pada Gambar 7. dan Gambar 8. ditunjukkan pemanfaatan view menuju kawasan berupa elemen arsitektural pada sisi jalan potensial.

\section{H. Analisa Orientasi Bangunan}

1. Tujuan: menentukan orientasi untuk bangunan-bangunan yang direncanakan dalam pengembangan kawasan.

2. Dasar pertimbangan: Dimaksudkan untuk mendapatkan view yang teratur dalam kawasan secara optimal agar bangunan dapat terekspose secara maksimal dan juga dapat meningkatkan kinerja bangunan (pencahayaan dan penghawaan alami) sesuai dengan kondisi tapak setempat.

3. Hasil analisa berupa orientasi masa bangunan tertuju pada Jalan Sawo sebagai obyek wisata belanja.

I. Analisa Tampilan Bangunan

1. Tujuan: untuk menentukan penampilan bangunan yang sesuai dengan fungsi bangunan serta sesuai dengan konsep arsitektur lokalitas yang mendasarinya.

2. Dasar pertimbangan:

- Kesesuaian dengan histori dan ciri bangunan berarsitektur lokalitas kawasan.

- Kesesuaian dengan kegiatan dan fungsi ruang yang diwadahinya.

- Menunjukkan adanya kekhasan ciri fisik sehingga mudah dikenali

- Menarik perhatian calon pengunjung.

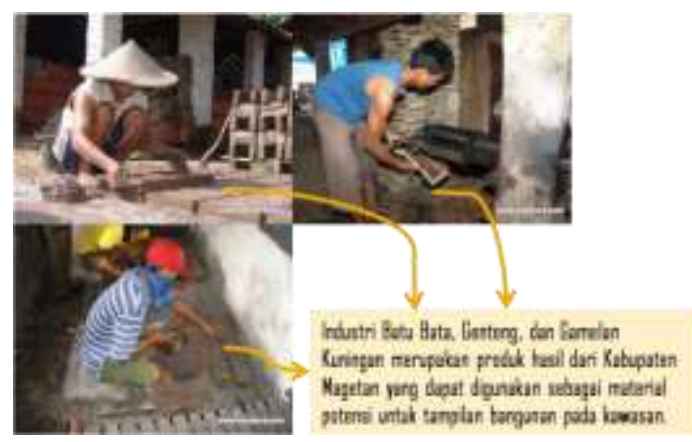

Gambar 9. Material Lokal

Pada Gambar 9. Ditunjukkan berbagai material lokal yang dimanfaatkan sebagai unsur tampilan bangunan.

J. Analisa Tata Masa Bangunan

1. Tujuan: menentukan pola tata masa bangunan pada kawasan berdasarkan sirkulasi kegiatan dalam kawasan.

2. Dasar Pertimbangan: Pengembangan pada kawasan Sentra Industri Kerajinan Kulit Jalan Sawo Kabupaten Magetan ini menetukan tata masa bangunan 
berdasarkan sirkulasi penduduk lokal dan wisatawan.

3. Hasil analisa: pola tata masa radial untuk kelompok ruang balai pelatihan, pola tata masa memusat untuk fasilitas penunjang pemukiman, dan pola tata masa linier untuk fasilitas penunjang kawasan wisata.

\section{KESIMPULAN (KONSEP DESAIN)}

Sentra Kerajinan Kulit Jalan Sawo Kabupaten Magetan sebagai Kawasan Wisata Industri merupakan sebuah kawasan yang di dalamnya terdapat beberapa fasilitas publik yang mendukung kegiatan dalam sentra kerajinan kulit sebagai wisata industri dengan masingmasing fungsinya masih saling terkait. Fasilitas yang disediakan berupa showroom kerajinan kulit beserta tempat produksi, tempat pelatihan sekaligus ruang pamer produk kerajinan kulit, serta fasilitas pendukung kawasan wisata, dengan konsep desain sebagai berikut:

\section{A. Kawasan Wisata Industri}

Pengembangan Sentra Kerajinan Kulit Jalan Sawo Kabupaten Magetan sebagai Kawasan Wisata Industri diwujudkan dengan penambahan fasilitas utama dan fasilitas penunjang kawasan wisata berupa:

$>$ Balai Pelatihan

Fasilitas penunjang berupa: showroom, tempat parkir pengrajin, ruang seminar, ruang ibadah, pos keamanan, unit toilet, dan kantin.

$>$ Jalur Pedestrian

Fasilitas penunjang berupa: spot rest, sidewalk garden, sculpture, pos keamanan, dan unit toilet.

$>$ Taman Parkir

Fasilitas penunjang berupa: pos keamanan, area terbuka hijau, area makan \& minum, dan unit toilet.

Penataan Kawasan Sentra Kerajinan Kulit Jalan Sawo Kabupaten Magetan mengoptimalkan lahan potensial dalam kawasan dengan mempertimbangkan sirkulasi penduduk lokal dan wisatawan serta mengutamakan kenyamanan seluruh pengguna kawasan wisata.

Desain rencana tapak pada Lampiran Gambar I

B. Redesain Showroom

$>$ Tipe A (bangunan sebagai showroom dan tempat tinggal)

A1 $(7 \mathrm{~m} \times 15 \mathrm{~m})$

A2 $(6 \mathrm{~m} \times 18 \mathrm{~m})$

A3 $(10 \mathrm{~m} \times 10 \mathrm{~m})$

A4 (12m x 8m)

Tipe B (bangunan sebagai showroom dan tempat produksi)

B1 (10m x 20m)

B2 $(10 \mathrm{~m} \times 15 \mathrm{~m})$

B3 $(10 \mathrm{~m} \times 7 \mathrm{~m})$

$>$ Tipe $\mathrm{C}$ (bangunan sebagai showroom tunggal)

C1 $(15 \mathrm{~m} \times 20 \mathrm{~m})$

C2 $(5 \mathrm{~m} \times 15 \mathrm{~m})$

C3 (7m x 12m)

C4 $(5 \mathrm{~m} \times 10 \mathrm{~m})$

C5 $(7 \mathrm{~m} \times 7 \mathrm{~m})$

C6 $(6 \mathrm{~m} \times 6 \mathrm{~m})$

$\sim$ Desain tipe A3 pada Lampiran Gambar II

\section{REFERENSI}

Profil Spesifikasi Kulit Tersamak Indonesia 2007. Pdf

Permenperind_No.130_2011_tentang Peta Panduan (road map) Pengembangan Kompetensi Inti Industri Kabupaten Magetan Tahun 2012-2016. pdf

http://formatnews.com/komoditi-eksporindonesia/

www.magetankab.go.id 